\title{
EDUCATING A NEW ENTREPRENEURIAL UNIVERSITY MODEL IN ISLAMIC AZAD UNIVERSITIES IN SISTAN AND BALUCHESTAN PROVINCE
}

\author{
EDUCAR UN NUEVO MODELO DE UNIVERSIDAD EMPRESARIAL EN LAS UNIVERSIDADES \\ ISLÁMICAS DE AZAD EN LAS PROVINCIAS DE SISTÁN Y BALUCHESTAN
}

\section{EDUCANDO UM NOVO MODELO DE UNIVERSIDADE EMPREENDEDORA NAS UNIVERSIDADES ISLÂMICAS DE AZAD, NO SISTÃO E NA PROVÍNCIA DO BALUCHISTÃO}

\author{
Hamid Okati ${ }^{1}$ \\ Masoud Pourkiani ${ }^{2}$ \\ Farzaneh Beikzadeh Abbasi ${ }^{3}$ \\ Navid Fatehi Rad ${ }^{4}$
}

\begin{abstract}
The purpose of this study was to educate the entrepreneurial university model in the Islamic Azad universities, Sistan and Baluchestan province. The statistical population of the expert group of entrepreneurs included entrepreneurship faculty and top entrepreneurs, managers, experts, and faculty members at the Islamic Azad University of Sistan and Baluchestan Province, which the education will conduct taking them as role model. The sampling was done by stratified random sampling method, and 558 questionnaires were gathered. The questionnaires were prepared by the experts on the basis of approved indicators via the Delphi questionnaire after confirming a model for promoting the development level of the universities of the province. Data were analyzed using SPSS and AMOS software. The results showed that there was a significant difference between the components of the entrepreneurial university and the Islamic Azad University in the presented model $(p<0.05)$. It seems that for development of university entrepreneurship in the Islamic Azad universities in Sistan and Baluchestan, several institutional infrastructure reforms and institutional innovations need to be considered by all university members to promote entrepreneurial organizational culture.
\end{abstract}

Keywords: Entrepreneurship University, Entrepreneurship, Islamic Azad University, Sistan and Baluchestan.

\footnotetext{
${ }^{1}$ Islamic Azad University, Kerman, Iran.

${ }^{2}$ Islamic Azad University, Kerman, Iran.

${ }^{3}$ Islamic Azad University, Kerman, Iran.

${ }^{4}$ Islamic Azad University, Kerman, Iran.
} 
Resumo: El propósito de este estudio fue educar el modelo universitario emprendedor en las universidades islámicas Azad, en la provincia de Sistán y Baluchestan. La población estadística del grupo experto de emprendedores incluía profesores de emprendimiento y empresarios, gerentes, expertos y miembros de la facultad de la Universidad Islámica Azad de Sistán y la provincia de Baluchestan, que la educación llevará a cabo tomándolos como modelo a seguir. El muestreo se realizó mediante un método de muestreo aleatorio estratificado, y se recopilaron 558 cuestionarios. Los expertos prepararon los cuestionarios sobre la base de indicadores aprobados a través del cuestionario Delphi después de confirmar un modelo para promover el nivel de desarrollo de las universidades de la provincia. Los datos se analizaron utilizando el software SPSS y AMOS. Los resultados mostraron que hubo una diferencia significativa entre los componentes de la universidad empresarial y la Universidad Islámica Azad en el modelo presentado $(p<0.05)$. Parece que para el desarrollo del emprendimiento universitario en las universidades islámicas de Azad en Sistán y Baluchestan, todos los miembros de la universidad deben considerar varias reformas de infraestructura institucional e innovaciones institucionales para promover la cultura organizacional empresarial.

Palabras clave: Universidad de Emprendimiento, Emprendimiento, Universidad Islámica de Azad, Sistán y Baluchestan.

Resumo: $O$ objetivo deste estudo foi educar o modelo universitário empresarial nas universidades islâmicas de Azad, província de Sistan e Baluchestan. A população estatística do grupo de especialistas de empresários incluía professores de empreendedorismo e os principais empreendedores, gerentes, especialistas e membros do corpo docente da Universidade Islâmica Azad do Sistão e da Província do Baluchistão, que a educação conduzirá considerando-os como modelo. A amostragem foi realizada pelo método de amostragem aleatória estratificada e foram coletados 558 questionários. Os questionários foram preparados pelos especialistas com base em indicadores aprovados, através do questionário Delphi, após a confirmação de um modelo para promover o nível de desenvolvimento das universidades da província. Os dados foram analisados no software SPSS e AMOS. Os resultados mostraram que houve uma diferença significativa entre os componentes da universidade empreendedora e da Universidade Islâmica Azad no modelo apresentado $(p<0,05)$. Parece que, para o desenvolvimento do empreendedorismo universitário nas universidades islâmicas Azad, no Sistão e no Baluchistão, várias reformas de infraestrutura institucional e inovações institucionais precisam ser consideradas por todos os membros da universidade para promover a cultura organizacional empreendedora.

Palavras-chave: Universidade de Empreendedorismo, Empreendedorismo, Universidade Islâmica de Azad, Sistão-Baluchistão.

\section{INTRODUCTION}

The process of predicting the pace of fluctuations in an era of complexity, turbulence, and discontinuous variation is quite difficult (Moosavi et al., 2017), so it seems necessary to utilize a tool with a constant characteristic in the current world which (Sterman, 2000), has the ability to reduce environmental ambiguity and increase the dominance of the internal environment. In fact, the factor which can remove such ambiguity is knowledge (Abedi et al., 2017); thus, the use of knowledge can lead to the individual and organizational success in this modern dynamic environment ( $\varnothing$ ystein Widding, 2005). Innovative and complex concepts such as knowledge-based economy, information society, and knowledge-based organizations represent new developments in both knowledge and information society (Mousavi et al., 2019). The factor which will leave the 
greatest impact on one's future is the wayhe responds to these developments, and the role of education, especially higher education, is of great importance. In such modern society, universities play a key role upon which all activities and decisions rely, since university is theinspirer of creativity and talent whose main goal is to create, build, and control new technologies (Salehi Omran, 2010).

The basis of the knowledge economy which is an important factor of production is the utility of knowledge instead of labor, capital, and raw materials. In this way, universities can be regarded as the producers of knowledge, so the industry will be its user, so following the same direction, they complement each other (Idis, 2005). The age of the university as a social institution dates back to 800 years ago, yet for long it was used just as an educational sector (Bahram Chubin et al., 2016). Regarding the university structure and the effects of the outside world on higher education structures, two great revolutions took place in the university system of the world. In the first revolution, which occurred dominantly in Germany late in the $19^{\text {th }}$ century, the one-dimensional educational system changed into an educational and research system, and universities dealt with both educational and research activities (Martin, 2007). During the second revolution, universities were not just the producer and distributor of knowledge, but they were also in charge of providing technological innovation, which then, led to economic and social development. Therefore, individual training became organization training (entrepreneurship education) and individual research turned into group research (Faramarzinia et al, 2016).

In the global perspective designed by UNESCO in 2004 for the $21^{\text {st }}$ century higher education (UNESCO, 2004), modern universities are defined as a site where entrepreneurial skills in higher education develop to potentiatethe graduates' capabilities into to entrepreneurs (Fatanatfard \& Mahmoudi, 2016).

There are numerous definitions for entrepreneurial universities. In general, an entrepreneurial university is a place which takes advantage of entrepreneurial management tools and system approach to match educational activities with the needs of current and future worlds (Yahya Pour \& Ghasem Nejad, 2012). In his definition, Clark has called for the active attempts of a university to create innovation, especially in business, stating that an entrepreneurial university is innovative andrisk- taking, and produces entrepreneurial behaviors (Din et al, 2016). Likewise, Ropkesummarizes the general themes and concepts of the entrepreneurial university in three parts: 1) university as an entrepreneurial organization; 2) members of university including faculty, students, and other staff equipped with the characteristics of an entrepreneur; and 3) interactions 
between the university and its external environment which rely on entrepreneurial attitudes (Hamze, 2015).

In essence, entrepreneurship provides a way for university development upon which university autonomy is defined, so that the university can ensure that it is possible to provide financial resources in other ways and reduce its dependence on the state. As a consequence, it will be able to develop new activities in accordance with the needs of the community and make fundamental changes in its structure to guarantee the capacity of the university in dealing with changes (Peterka, 2011). Therefore, these universities have been boosted due to significance of knowledge in the field of industry and economy, and become responsible for transferring creativity, innovation, and new technology to society (Leila, 2015).).

In Iran, because of various economic, social, and cultural problems which have degraded theperformance and role of traditional universities as well as their identity and their commitments toward the community, the issue of entrepreneurship is significantly considered in the Third Economic, Social and Cultural Development Program which in turn has led to the practical plan. The plan aims to carry out activities such as establishment of communication offices with industry and society, technology transfer offices, academic branch offices, science and technology parks and business growth centers, knowledge-based companies, and establishment of entrepreneurship centers, all of which are major infrastructures of this era for entrepreneurship universities. Seemingly, Iranian universities need to review their goals and missions to adapt to the environment and fulfill their commitment to the social and economic development of the country. Universities will follow the path of serving the country's development and dynamism just when they can formulate their knowledge and expertise in industrial production and take steps to research and respond to the social and industrial needs. Today, society needs the assistance and support of universities and higher education institutions more than ever. Universities need to be places equipped for long-term research. Given the mission of producing knowledge and training the expert manpower with new thoughts and notions, the entrepreneur university can, at any moment, inject a new vigor into the vital arteries of a society with growing mercy. On the other hand, society can employ emerging ideas of the academics to realize the idea of development (Graham, 2019).

Since one of the educational centers in the country is the Islamic Azad University, which as a key phenomenon of higher education and a crucial and significant institutions in the Islamic society of Iran has taken a major part in the burden of higher education responsibilities and has an increasing impact on educational, cultural, socio-economic development at the community level, it 
is necessary to consider the development of its entrepreneurship. Regarding the above- mentioned issues, the main objective of this research is to provide and validate the model of entrepreneurial university in the Islamic Azad universities of Sistan and Baluchistan province. The research questions are as follows:

1- What are the components of Entrepreneurial University and Islamic Azad University to present a sustainable model in Sistan and Baluchistan province?

2- How is the status of the components of entrepreneurial university and Islamic Azad University to offer a sustainable model in Sistan and Baluchistan province?

3- What are the characteristics of the proposed model based on the components of the entrepreneurial university to present a sustainable model in the Islamic Azad University of Sistan and Baluchistan province?

\section{RESEARCH BACKGROUND}

(Hamze, 2014) studied the status of an entrepreneurial university indices based on the 2012 Gibb model at Tehran University. The findings which resulted from data analysis of 271 questionnairesfilled out by the faculty members of Tehran University indicated that the components of the outlook, the mission and strategy of the university, the governance and administration of the university, the structure and design of the organization, the multidisciplinary, the transdisciplinary, the power of influence, the management of the stakeholders and community values; the graduates; the knowledge transfer; the growth center; the risk financing in all firms branching from the university are in a relatively favorable condition, whereas the components of internationalization and entrepreneurial education and investment are in a unfavorable situation. In addition, the general status of the entrepreneurial university indices based on the Gibb model at Tehran University is rather favorable. (Abedi et al., 2017) developed the model of entrepreneurial university of Agriculture and Natural Resources from the perspective of Agricultural Education Management. The result of data analysis using exploratory factor analysis revealed that organizational, teachinglearning, curriculum development, differences between an entrepreneurial university and natural resources with entrepreneurial university in other process disciplines and activities can be regarded as some components of an entrepreneurial university of an agriculture and natural resources university. (Tofighi \& Nurshahi, 2012) carried out their study with the aim of "studying and explaining the entrepreneurial capacity of selected universities in Mazandaran province". The 
findings of the study which were based on the data collected from the five selected universities in the province indicated that the overall model with the fitting indices (RMSEA $=0.067, N F I=0.95$, and $\mathrm{GFI}=0.92$ ) was confirmed. Further, the entrepreneurship capacity and its related dimensions in the evaluated universities were in poor condition. studied the "factors affecting the entrepreneurship of medical universities in Iran's higher education system". The results indicated 9 factors affecting the entrepreneurship of universities. The greatest explanatory power was the factor of considering entrepreneurship as the strategic priority of the university and the least explanatory power belonged to the academic curriculum development. The results of designing the entrepreneurial university model from the perspective of organizational entrepreneurship revealed that this model includes the components such asthe quality of the graduate, the dissemination of scientific findings, attracting financial resources, research contracts, patents, creating productive businesses, founding science and technology parks, entrepreneurial enterprise culture, flexible organizational structure, entrepreneurial approach of professors, macro management, course content, and students' characteristics. (Hossein Gholizadeh, 2012). evaluated the entrepreneurship indices at Mazandaran University based on fuzzy method. The findings of this study showed that the characteristics and indices of the entrepreneurial university in Mazandaran University are the components of the vision, mission, and strategy of the university; governance and administration of the university; organizational structure, multidisciplinary and transdisciplinary approach; power of influence and use of diverse resources; stakeholder management and community values; the graduate, knowledge transfer, growth centers, risk financing in university-based firms, internationalization, and ultimately, entrepreneurial education and investment training were at an inappropriate level.

(Davami, 2012) examined the effectiveness of entrepreneurship education programs in promoting entrepreneurial skills among state-run university students. The results showed that the entrepreneurship program at the university was very effective in raising the level of entrepreneurial skills of the students; therefore, entrepreneurship skills and activities can be supported through education and entrepreneurship at the state universities, so the role of the ministry of education is quite significant in promoting the highly entrepreneurial culture. In a research seeking to recognize the components of an entrepreneurial university, identified four areas of mission and values, development of the mentally-minded, strong command center, and the resources as various parts of the process of implementing an entrepreneurial university. (Graham, 2019) also conducted a research on the leading entrepreneurial universities in 19 countries, and showed that the key factors in creating an entrepreneurial university are: interaction of entrepreneurs and innovators across 
academic and regional communities, ability to research supported by financially by industry, grant licenses from technology-driven universities, corporate innovation and entrepreneurship agenda which are reflected in policies, missions, budget allocations, incentives, and curriculum development. (Peterka \& Salihovic, 2012) also concluded that environmental indicators, teaching, knowledge transfer, staffing, financial resources, government, and management are the vital indicators of the entrepreneurial university.

\section{METHOD}

The research method in this study which is descriptive and correlational, has collected data through field research. This process was done in several steps to collect data and achieve the desired goals. Indicator extraction phase was performed through content analysis based on previous research indicators. Delphi questionnaire setup phase was also performed to confirm the extractives index by the expert group. Next was the stage of determining the status quo indicators. The stage of determining the desirable status of indicators was based on the Delphi process. The comparison phase of the situation of the desirable condition indicators was also based on the results of the previous two stages. Thestage of model presentation was also based on the previous stage to promote the development level of Azad Universities of Sistan and Baluchestan province, and finally, the validity of the model was evaluated using a researcher-made questionnaire and a panel of experts.

The statistical population of the present study consists of two groups: the first group of entrepreneurial experts includes entrepreneurship faculty and superior entrepreneurship-familiar entrepreneurs. Of course, their exact number is unknown since they are located across the country, so their selection is random. They were required to possess qualifications such as knowledge and experience in the subject, willingness, enough time for the company and effective communication skills, having scientific research and articles related to the subject of research, availability, and experience, suitability of the field of study, PhD degree, and university employment. Inthis research, their opinions and comments were used in designing and developing the research model. The second group consists of directors, experts and faculty members in the Islamic Azad University of Sistan and Baluchestan province, engaged in 7 academic units of this province.

The sample size was 5 to 10 times the number of questions in the questionnaire. This number can be changed from 275 to 550 depending on the amount stated. Considering the probability of 
the inappropriate use of some completed questionnaires, a total of 570 questionnaires were distributed randomly and at different hours of the day, and finally, 558 questionnaires were used as the basis for the statistical analysis.

A questionnaire was used to collect required data.

1- Model design and validation questionnaire completed by 30 experts and elites in entrepreneurship.

2- $\quad$ Final questionnaire was filled out by 558 experts and elites in entrepreneurship, faculty, managers and experts of Islamic Azad University of Sistan and Baluchestan.

The validity of the questionnaires was first examined and verified in terms of verbal and conceptual validity by 25 elites. Then, its content validity, 0.825 , was obtained via content validityratio (CVR). In order to ensure the validity of the data and to verify the accuracy of the sampling before factor analysis, Kaiser, Mayer, and Olkin criteria (KMO) were used. According to the findings, the KMO value for sampling quality is equal to 0.912 , which is an acceptable value, and due to the significance of Bartlett's test of sphericity $(p<0.05)$, there are necessary conditions for performing factor analysis. The internal reliability was calculated using Cronbach's alpha to check internal reliability, and, given that the Cronbach's alpha values were higher than 0.7 , the internal reliability of all variables was confirmed.

In the present study, structural equation modeling was used at the descriptive level of mean and standard deviation and inferential statistics. Also, structural relationship model was used for data analysis. Statistical SPSS and AMOS were used to analyze the data.

\section{FINDINGS}

Question 1: What are the components of Entrepreneurial University and Islamic Azad University to present a sustainable model in Sistan and Baluchestan province?

In order to find effective components from the viewpoint of the experts participating in the Delphi method, the average of respondents' views was compared with the t-test and the theoretical amount (3.00). The results of (Table 1) show that all proposed components have been approved by the experts; therefore, components of the shared vision, future strategy, entrepreneurial university culture, continuous interaction with environment, entrepreneurial university structure, financial independence, human resources, customer orientation, entrepreneurial leadership, incentive 
system and Knowledge investment as the components of entrepreneurship and Islamic Azad University was used in this research.

Table 1- Reviewing Respondents' Comments about proposed components $(n=30)$

\begin{tabular}{|c|c|c|c|c|}
\hline \multirow[t]{2}{*}{ Components } & \multicolumn{2}{|c|}{ EntrepreneurUniversity } & \multicolumn{2}{|c|}{ IslamicAzadUniversity } \\
\hline & Mean & tstatistics & Mean & tstatistics \\
\hline Shared View & 4.38 & $* * 17.05$ & 3.54 & $12.24 * *$ \\
\hline Future strategy & 4.37 & $* * 14.32$ & 3.68 & $* * 9.69$ \\
\hline $\begin{array}{l}\text { Entrepreneurial } \\
\text { organizational }\end{array}$ & 4.67 & $* * 20.08$ & 3.37 & $* * 4.18$ \\
\hline $\begin{array}{l}\text { Continuous interaction with } \\
\text { the environment }\end{array}$ & 4.17 & $* * 17.92$ & 3.39 & $* * 5.46$ \\
\hline $\begin{array}{l}\text { Entrepreneurial Academic } \\
\text { Structure }\end{array}$ & 4.05 & $* * 18.27$ & 3.56 & $* * 6.08$ \\
\hline Financial Independence & 3.77 & $* * 7.18$ & 3.63 & $* * 4.26$ \\
\hline Human resources & 4.07 & $* * 36.35$ & 3.47 & $* * 6.20$ \\
\hline Customer Satisfaction & 4.23 & $* * 19.34$ & 3.55 & $* * 9.80$ \\
\hline Entrepreneurial Leadership & 4.41 & $* * 18.13$ & 3.27 & $* * 2.40$ \\
\hline Incentive system & 4.44 & $* * 14.77$ & 3.51 & $* * 3.60$ \\
\hline Know Ledge Capitalization & 4.49 & $* * 17.72$ & 3.47 & $* * 4.17$ \\
\hline
\end{tabular}

Question 2: How are the components of the University of Entrepreneurship and Islamic Azad University to present a sustainable model in Sistan and Baluchestan province?

Based on the empirical mean score in Islamic Azad University and the scale of Bazargan et al. (1999) (Tables 2) and (Tables 3), the components of the shared vision, future strategy, entrepreneurial organizational culture, entrepreneurial structure, human resources, customer orientation, incentive system, and knowledge capitalization in Islamic Azad University is in unfavorable condition ( average view of respondent $<3$ ).

Also, the components of continuous interaction with environment, financial independence, and entrepreneurial leadership in Islamic Azad University have been in a favorable situation (average view of respondent>3). 
Table 2- Ranking Scale by Abbas Bazargan et al

\begin{tabular}{ccccccc}
\hline Very strong & Strong & Good & $\begin{array}{c}\text { More than } \\
\text { satisfactory }\end{array}$ & Satisfactory & Border & Unfavorable \\
\hline $4.4-51.92$ & $4.4-1.49$ & $3.3-61.99$ & $3.3-1.59$ & $2.2-51.99$ & $2.2-1.49$ & $<\mathbf{2}$ \\
\hline
\end{tabular}

Table 3- Description of Variables among Subjects

\begin{tabular}{|c|c|c|c|c|c|c|}
\hline Component & University type & No. & Mean & SD & Min & Max \\
\hline \multirow[t]{2}{*}{ Shared vision } & Entrepreneur & 281 & 4.05 & 0.42 & 2.8 & 5.00 \\
\hline & IslamicAzad University & 277 & 2.69 & 0.68 & 1.4 & 4.40 \\
\hline \multirow{2}{*}{$\begin{array}{l}\text { Future } \\
\text { strategy }\end{array}$} & Entrepreneur & 281 & 3.84 & 0.49 & 2.80 & 5.00 \\
\hline & IslamicAzad University & 277 & 2.87 & 0.68 & 1.40 & 4.60 \\
\hline \multirow{2}{*}{$\begin{array}{l}\text { Entrepreneurial } \\
\text { organizational } \\
\text { Culture }\end{array}$} & Entrepreneur & 281 & 4.06 & 0.49 & 2.80 & 5.00 \\
\hline & IslamicAzad University & 277 & 2.33 & 0.55 & 1.40 & 4.80 \\
\hline \multirow{2}{*}{$\begin{array}{l}\text { Interaction with } \\
\text { Environment }\end{array}$} & Entrepreneur & 281 & 3.99 & 0.37 & 3.20 & 5.00 \\
\hline & IslamicAzad University & 277 & 3.20 & 0.91 & 1.40 & 4.40 \\
\hline \multirow{2}{*}{$\begin{array}{l}\text { Entrepreneurial } \\
\text { Structure }\end{array}$} & Entreprener & 281 & 3.65 & 0.39 & 2.8 & 4.40 \\
\hline & IslamicAzad University & 277 & 2.71 & 1.43 & 1.40 & 4.20 \\
\hline \multirow{4}{*}{$\begin{array}{l}\text { Financial } \\
\text { Independence } \\
\text { Human esources }\end{array}$} & Entrepreneur & 281 & 3.43 & 0.40 & 2.40 & 5.00 \\
\hline & IslamicAzad University & 277 & 3.10 & 0.56 & 1.40 & 4.00 \\
\hline & Entrepreneur & 281 & 4.06 & 0.32 & 3.20 & 4.80 \\
\hline & IslamicAzad University & 277 & 3.02 & 0.48 & 1.60 & 4.40 \\
\hline \multirow{4}{*}{$\begin{array}{l}\text { Customer } \\
\text { orientation } \\
\text { Entrepreneurial } \\
\text { Leadership }\end{array}$} & Entrepreneur & 281 & 4.12 & 0.51 & 3.00 & 5.00 \\
\hline & IslamicAzad University & 277 & 2.68 & 0.67 & 1.20 & 4.60 \\
\hline & Entrepreneur & 281 & 4.22 & 0.24 & 3.80 & 4.80 \\
\hline & IslamicAzad University & 277 & 3.19 & 0.57 & 2.00 & 4.40 \\
\hline \multirow{2}{*}{$\begin{array}{l}\text { Incentive } \\
\text { system }\end{array}$} & Entrepreneur & 281 & 4.20 & 0.30 & 3.60 & 5.00 \\
\hline & IslamicAzad University & 277 & 2.80 & 0.62 & 1.40 & 4.20 \\
\hline \multirow{2}{*}{$\begin{array}{l}\text { Knowledge } \\
\text { capitalization }\end{array}$} & Entrepreneur & 281 & 4.36 & 0.28 & 3.80 & 5.00 \\
\hline & IslamicAzad University & 277 & 2.75 & 0.72 & 1.40 & 4.40 \\
\hline
\end{tabular}

Question 3: What are the characteristics of the proposed model based on the components of the entrepreneurial university to present a sustainable model in Islamic Azad University of Sistan and Baluchistan?

At this stage, according to the research model, a questionnaire consisting of 55 questions was designed and the structural equation modeling approach was used to examine the suggested pattern of research. The software output indicates the suitability of the proposed research model, 
so that the root mean square error estimate (RMSEA) is equal to (0.051), the normalized Chi-Square (CMIN / DF) is equal to (2.091), and the index value of Goodness of fit (GFI) is equal to (0.927) (Table 4).

Table 4- Entrepreneurship University Components Pattern and Fitment Index

\begin{tabular}{lcc}
\hline \multicolumn{1}{c}{ Index } & Acceptable amount & Reported value \\
\hline $\begin{array}{l}\text { The root mean square error estimate } \\
\text { (RMSEA) }\end{array}$ & $\geq 0.08$ & $\mathbf{0 / 0 5 1}$ \\
Normalized Chi-Square (CMIN / DF) & $\geq 3$ & $\mathbf{2 . 0 9 1}$ \\
Goodness Fit Fitness Index (GFI) & $\leq 0.9$ & $\mathbf{0 . 9 2 7}$ \\
The modified fitness index (AGFI) & $\leq 0.9$ & $\mathbf{0 . 9 0 9}$ \\
Adequacy fit index (CFI) & $\leq 0.9$ & $\mathbf{0 . 9 3 0}$ \\
Normative fit index (NFI) & $\leq 0.9$ & $\mathbf{0 . 9 2 0}$ \\
Tucker-Lewis index (TLI) & $\leq 0.9$ & $\mathbf{0 . 9 2 1}$ \\
Incremental fitting index (IFI) & $\leq 0.9$ & $\mathbf{0 . 9 3 1}$ \\
\hline
\end{tabular}

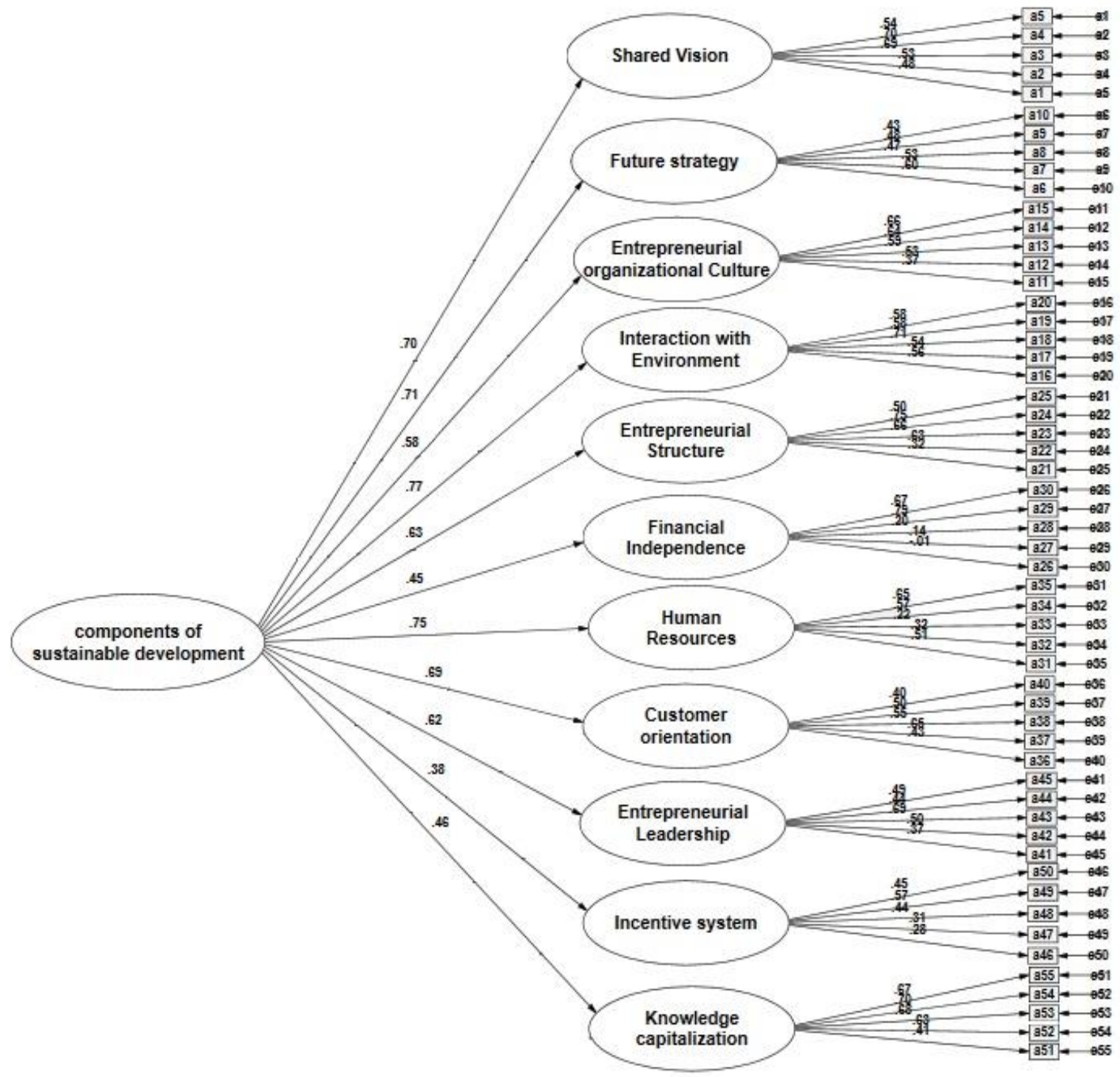

Figure 1- Results of Confirmatory Factor Analysis of Components of Entrepreneurial University (Standardized Factor Load) 
Chi-square test was used to examine whether there is a significant difference between the components of entrepreneurial university and Islamic Azad University in the presented model (Figure 1). The results of (Tables 5) show that there is a significant difference between the components of the joint perspective, prospective strategy, entrepreneurial structure, incentive system, and knowledge capitalization in the entrepreneurial university and Islamic Azad University ( $p<0.05$ ), yet, no difference was recorded between the components of entrepreneurial organizational culture, continuous interaction with environment, financial independence, human resources, customer orientation and entrepreneurial leadership $(p<0.05)$.

Table 5- Analysis of Difference between Components of Entrepreneurial University and the studied Islamic Azad University

\begin{tabular}{|c|c|c|c|}
\hline Component & University & $\begin{array}{c}\text { Path } \\
\text { coefficient }\end{array}$ & Chi-SquareDifference \\
\hline \multirow{3}{*}{ Shared vision } & Entrepreneur & 0.704 & \multirow[t]{2}{*}{$2.28^{* * *}$} \\
\hline & Islamic Azad University & 0.592 & \\
\hline & Entrepreneur & 0.713 & \multirow[t]{2}{*}{$3.21^{* *}$} \\
\hline future strategy & Islamic Azad University & 0.545 & \\
\hline \multirow{4}{*}{$\begin{array}{l}\text { Entrepreneurial organizational } \\
\text { Culture } \\
\text { Interaction with Environment }\end{array}$} & Entrepreneur & 0.575 & \multirow[t]{2}{*}{-0.21} \\
\hline & Islamic Azad University & 0.587 & \\
\hline & Entrepreneur & 0.765 & \multirow[t]{2}{*}{-1.26} \\
\hline & Islamic Azad University & 0.806 & \\
\hline \multirow[t]{2}{*}{ Entrepreneurial Structure } & Entrepreneur & 0.625 & \multirow[t]{2}{*}{$-2.35^{* *}$} \\
\hline & Islamic Azad University & 0.732 & \\
\hline \multirow[t]{2}{*}{ Financial Independence } & Entrepreneur & 0.451 & \multirow[t]{2}{*}{1.05} \\
\hline & Islamic Azad University & 0.377 & \\
\hline \multirow[t]{2}{*}{ Human Resources } & Entrepreneur & 0.751 & \multirow[t]{2}{*}{0.05} \\
\hline & Islamic Azad University & 0.749 & \\
\hline \multirow[t]{2}{*}{ Customer orientation } & Entrepreneur & 0.687 & \multirow[t]{2}{*}{0.60} \\
\hline & Islamic Azad University & 0.659 & \\
\hline \multirow[t]{2}{*}{ Entrepreneurial Leadership } & Entrepreneur & 0.620 & \multirow[t]{2}{*}{0.04} \\
\hline & Islamic Azad University & 0.597 & \\
\hline \multirow[t]{2}{*}{ Incentive system } & Entrepreneur & 0.375 & \multirow[t]{2}{*}{$-5.02^{* *}$} \\
\hline & Islamic Azad University & 0.676 & \\
\hline \multirow[t]{2}{*}{ Knowledge capitalization } & Entrepreneur & 0.457 & \multirow[t]{2}{*}{$-4.58^{* *}$} \\
\hline & Islamic Azad University & 0.708 & \\
\hline
\end{tabular}

** Significant at the level of $0.01,{ }^{*}$ significant at the level of 0.05 
Finally, in order to investigate and determine the effective model of the proposed research, the conceptual model and the results of the questionnaire were presented to the experts who participated in the design of the model, and they were asked to take into account the conceptual model. Theresults obtained from the research questionnaire tests determine the effectiveness of the proposed model showed that 25 (100\%) of the experts confirmed the effectiveness of the model.

\section{DISCUSSION}

The results showed that, based on the survey of the respondents' comments (Delphi method-oriented experts' opinion), the components evaluated to provide a sustainable model at the University of Entrepreneurship and the Islamic Azad University include: a shared vision, future strategy, Entrepreneurial Academic Culture, continuous interaction with environment, entrepreneurial university structure, financial autonomy, human resources, customer orientation, entrepreneurial leadership, incentive system, and knowledge capitalization. In terms of the status of the evaluated indicators or components, the components of the shared vision, future strategy, entrepreneurial organizational culture, entrepreneurial structure, human resources, customer orientation, incentive system, and knowledge capitalization were in an unfavorable condition in the Islamic Azad University, whereas the components of continuous interaction with environment, financial independence, and entrepreneurial leadership were in a favorable situation.

In explaining and justifying these results, it can be noted that an organization will have a shared vision and a future strategy which focuses on the vision of the organization regarding the participation of the individuals and, on the other hand, reaches an awareness of and commitment on the part of the organization. Managers will also develop their strategies about the future. To strengthen the entrepreneurial structure among the staff and managers of the university, it is possible for the university to create greater commitment to its own perspective, of course, it will be possible by providing information on different aspects of the perspective to the managers and the employees. In the economic development of modern societies, knowledge is the most crucial element, and the future of these societies which is seeking a dynamic economy relies on increasing competition and the desire for growth and innovation. In such a situation, university becomes the most influential institution in a knowledge- based society. Hence, universities and higher education systems which are moving toward further integration with the process of indigenous, regional, and 
international economic development will shift their traditional role, which is simply the production of knowledge, to entrepreneurship universities that, in addition to producing knowledge and creating ideas, will attempt to put this knowledge into practice. In fact, the concept of knowledgebased development and the orientation of the country's development plans have imposed an entrepreneurial mission to universities.

Unfortunately, in Iran, most universities are research-based and have little business in terms of commercializing research findings, training entrepreneurs, and changing into entrepreneurial universities (Salamzadeh et al, 2011). Moreover, the interaction with elites and academics and the application of scientific capacities of universities, especially in case of dealing with industries and companies, has been greatly ignored (Faez \& Shahabi, 2010).

The main task of each university, i.e., addressing the entrepreneurship and education of the graduates who have the skills and abilities needed to set up a business is also disregarded. Unfortunately, this is very evident among the universities of the country. Today, such universities have become centers for responding to the needs of the students in terms of getting certificates rather than meeting the social needs of the students (Abou Zeid, 2002) Itshould be acknowledged that although there are currently different plans and programs to support entrepreneurship development in universities and commercialization of research within the country have been somehow implemented, recent studies suggest that the state of entrepreneurship in the universities is still unfavorable.

\section{CONCLUSION}

For the development of university entrepreneurship in the Islamic Azad universities in Sistan and Baluchestan, the institutional and institutional reforms should be taken into consideration by all university members in order to promote entrepreneurial organizational culture. Moreover, all stakeholders, policymakers, managers, and faculty members of these universities should try to strengthen and support the culture and put especial priority toimplementing this approach at the university. The Islamic Azad Universities in Sistan and Baluchestan should do their best to stabilize the entrepreneurial characteristics and improve the university's relationship with other universities and research and educational centers at both national and international levels. In fact, the entrepreneurial university needs to be more flexible, especially in response to the everchanging demands of the environment. This flexibility is not possible unless the dimensions of the universities 
change. A flexible structure requires a modification in the standards and normal rules and regulations. In turn, this will improve the complexity of such organizations, that is, universities will seek to reduce their organizational levels, the number of occupational levels, and the dispersion of locations and geographical areas. Moreover, to accelerate decision-making, they need to adopt decentralization and decentralized structures. The university should provide adequate conditions for quick and transparent transmission of information and communication to the organization and, in fact, create a mutual means of communication. In this way, monitoring at universities will turn from the strict control to a general one.

\section{SUGGESTIONS}

Based on the results, it is recommended that toimplement entrepreneurial university indices in universities, the allocation of budget be directed toward entrepreneurial activities with a more appropriate policy. Also, it is necessary to invest in the university brand as an entrepreneurial university, and improve the university's relationship with other universities and research and education centers at the national and international levels. University leaders and managers need to gain better understanding, expertise, and high performance on the concept of an entrepreneurial university. Entrepreneurship counseling centers and knowledge-based knowledge centers should be founded to meet the growing needs and demands of the environment and the students. Activating research activities, creating research bases with commercial potential, and entering the domestic and foreign markets require possessing a flexible structure in which the standard rules and regulations are reduced. Decentralization and decentralized structure are also essential. Information and communication should flow transparently and quickly throughout the organization, and in fact, it needs to be a two-way communication. Controlling the organization should change from intense control to overall monitoring. Having a proper financial independence and providing independent funding for all activities can also work. Hiring or training a desirable human resource at the university is inevitable. The university should place its principle of the initiative on strengthening itself and creating a space to support and support the innovative activities of the individuals. 


\section{ACKNOWLEDGEMENTS}

The reported analysis of the data collected in this paper is part of the PhD dissertation.

\section{REFERENCES}

Moosavi M. \& Nowruz Khalil M, \& Azadi Ahmadabadi J. (2017). Identifying and Prioritizing Dimensions and Components Effective on Structure of Entrepreneurial University: A Suggestion for Success in the Third Generation Universities. Journal of Technology Growth, 13 (52): 8-14.

Sterman J. (2000). Business dynamics: systems thinking and modeling for a complex world, 14 (7): 121-130.

Abedi B. \& Baradaran M. \& Khosravi Pour B. \& Yaghoobi J. \& Yazdanpanah M. (2017). Developing an Entrepreneurial University Model of Agriculture and Natural Resources from Perspective of Agricultural Education Management. Agriculture Management Research, 40 (6): 123-139.

$\varnothing$ ystein Widding, L. (2005). Building entrepreneurial knowledge reservoirs. Journal of Small Business and Enterprise Development, 12(4), 595-612.

Mousavi H. \& Salehi Omran I. \& Farastkhah M. \& Tofighi J. (2019). Presentation of Entrepreneur University Development Model in Iran, Iran Engineering Education, 19 (76), 1-28.

Salehi Omran I. (2010). Theoretical Approaches to Industrial Education Curriculum. Curriculum Studies of Iran, 5 (19), 8-42.

Aidis R. (2005). Institutional barriers to small-and medium-sized enterprise operations in transition countries. Small business economics, 25(4), 305-317.

Bahram Chubin M. \& Mushref Javadi M. \& Safari A. (2016). Evaluation and Ranking of the Entrepreneurial University Criteria (Case Study: Isfahan University Universities), Entrepreneurship Development. 9 (4), 691-710.

Martin B. (2007). The changing social contract for science and the evolution of the university. Science and innovation: Rethinking the rationales for funding and governance. Edward Elgar, Cheltenham. 6 (1), 17-29.

Faramarzinia Z. \& Farhadi Rad H. and Mehr Alizadeh Y. (2016). An Analysis of Possibility of Implementing University of Entrepreneurship Model at Shahid Chamran University of Ahwaz. Engineering Education Iran, 18 (71), 65- 86.

Fatanatfard M. \& Mahmoudi H. (2016). Criticism on University Entrepreneur, 13 (2), 411- 420, Retrieved from: http://amoozeshalee.ir/article-1-78-fa.pdf

Yahya Pour O. \& Ghasem Nejad M. (2012). Cultural Setting at Entrepreneurial University. Work and Society, 15 (142), 51- 57.

Din B. \& Anuar A. \& Usman M. (2016). The effectiveness of the entrepreneurship education program in upgrading entrepreneurial skills among public university students. Procedia-Social and Behavioral Sciences, 224 (1), 117-123.

Hamze F. (2015). Investigating and Explaining Entrepreneurial Capacity of Selected Universities of Mazandaran Province. Governmental Management, 7 (1), 111- 132.

Peterka S. (2011). Entrepreneurial university as the most important leverage in achieving knowledge-based societyThe Ninth International Conference: Challenges of Europe: Growth and Competitivness - Reversing the Trends, Faculty of Economics University of Split, Croatia, 5 (4), 26 28.

Leila N. (2015). Factors Affecting Entrepreneurship of Medical Universities in Iran's Higher Education System, Health and Care Management, 6 (4), 49-60. 
Graham R. (2019). Conceptual Model Design of Entrepreneurial University with Organizational Entrepreneurship Approach. Entrepreneurship Development, 18 (26), 697-714.

Hamze G. (2014). Evaluation of entrepreneurial university indices in Mazandaran University based on Fuzzy Method. Entrepreneurship Development, 7 (2), 369-388.

Tofighi J. \& Nurshahi N. (2012). Providing solutions for Development of Cooperation between Universities and Industry in Iran. Iran Engineering Education, 14 (46), 75- 95.

Hossein Gholizadeh R. (2012). Essential Requirements for University Interaction with Industry: Knowledge Management Approach. Engineering Education Iran, 14 (54), 1-19.

Davami P. (2012). A Model for Relationship between Industry and University, Engineering Education, 14 (53), 119-129.

Peterka O. \& Salihovic V. (2012). What is entrepreneurial university and why we need it?. Economy of Eastern Croatia yesterday, today, tommorow. 1(1), 98-107.

Salamzadeh A. \& Salamzadeh Y. \& Daraei M. (2011). Toward a systematic framework for an entrepreneurial university: a study in Iranian context with an IPOO model. Global Business and Management Research: An International Journal. 3(1): 30-37.

Faez A. \& Shahabi A. (2010). Assessment and Prioritization of Barriers in University Relations with Industry (Case Study: the city of Semnan). Leadership and Training Management, 4 (2), 97-124.

Abou Zeid E. (2002). A knowledge management reference model. Journal of knowledge management, 6(5), 486-499.

\section{$\underline{\text { ABOUT THE AUTHORS }}$}

\section{Hamid Okati}

PhD Candidate of Public Administration - Adaptive and Development, Department of Management, Kerman Branch, Islamic Azad University, Kerman, Iran. E-mail: hamidokati@yahoo.com

ORCID: https://orcid.org/0000-0001-6635-132X

\section{Masoud Pourkiani}

Assistant Professor, Department of Management, Kerman Branch, Islamic Azad University, Kerman, Iran. Email: pourkiani@iauk.ac.ir

ORCID: https://orcid.org/0000-0002-5370-3768

\section{Farzaneh Beikzadeh Abbasi}

Assistant Professor, Department of Management, Kerman Branch, Islamic Azad University, Kerman, Iran. Email: farzanehbigzadeh@yahoo.com

ORCID: https://orcid.org/0000-0002-2762-218X

\section{Navid Fatehi Rad}

Assistant Professor, Department of Management, Kerman Branch, Islamic Azad University, Kerman, Iran. Email: fatehi.iauk@gmail.com

ORCID: https://orcid.org/0000-0002-3611-0661 